\title{
NEOLIBERALISMO URBICIDA: A "CRISE" PRODUZIDA NA IN-SEGURANÇA PÚBLICA DO ESPÍRITO SANTO - BRASIL
}

\author{
Márcio José Mendonça \\ Cláudio Luiz Zanotelliz
}

\begin{abstract}
Resumo: $\mathrm{O}$ artigo reflete sobre o fenômeno do urbicídio que emergiu durante a crise da segurança pública no estado do Espírito Santo, em fevereiro de 2017, quando a Polícia Militar entrou em greve. Demonstra-se que a análise da violência política desencadeada durante a paralisação da polícia não deve ficar restrita a um enfoque episódico, centrado no estereótipo do banditismo, mas, sim, evidenciar a operacionalização da violência orientada por interesses políticos que foram induzidos contra o espaço urbano e grupos específicos, vistos a partir do cenário de militarização da cidade, do desmonte do Estado conduzido pelo governo local e por uma política de segurança pública fracassada e que se pauta, em muitas de suas intervenções, pela violência. $\mathrm{O}$ artigo ainda demonstra que o conceito de urbicídio pode ser empregado em análises em que não se verifica destruição completa do ambiente construído da cidade.
\end{abstract}

Palavras-chave: Urbicídio. Violência Política. Espírito Santo.

\section{URBIC NEOLIBERALISM: THE "CRISIS" PRODUCED IN THE PUBLIC IN-SECURITY OF ESPÍRITO SANTO - BRAZIL}

\begin{abstract}
The article reflects on the phenomenon of urbanization that emerges during the public security crisis in the state of Espírito Santo, in February 2017, when the Military Police went on strike. It is demonstrated that the analysis of political violence unleashed during the police stoppage should not be restricted to an episodic approach, centered on the stereotype of banditry, but rather to demonstrate the operationalization of violence oriented by political interests that were induced against the urban space and specific groups, seen from the scenario of militarization of the city, the dismantling of the state led by the local government and a failed public security policy that is based, on many of its interventions, by the violence. The article also demonstrates that the concept of urbicide can be used in analyzes in which there is no complete destruction of the built environment of the city.
\end{abstract}

Keywords: Urbicide. Political Violence. Espírito Santo.

\footnotetext{
${ }^{1}$ Universidade Federal do Espírito Santo - Ufes. marcioriei@hotmail.com

2 Prof. Dr. da Universidade Federal do Espírito Santo. clzanotelli@yahoo.com.br
} 


\section{INTRODUÇÃO}

O artigo oferece uma análise crítica sobre a crise da segurança pública no estado do Espírito Santo, Brasil, durante o mês de fevereiro de 2017, quando, em virtude da paralisação da Polícia Militar, o estado se viu tomado por atos de violência de grande proporção, estabelecendo um sentimento de medo e uma real insegurança no espaço urbano da Região Metropolitana da Grande Vitória (RMGV). Fugindo de análises pontuais e de alcance restrito na compreensão do fenômeno espacial do que se passava tanto na política econômica desenvolvida pelo Estado quanto na violência urbana desencadeada ao longo de 22 dias, o artigo apresenta um enfoque espacial do processo, mediante emprego do conceito de urbicídio, com o intuito de desnudar as práticas de violência política - dos agentes do Estado e fora do Estado - orientadas contra o espaço urbano e grupo de jovens negros e pobres, os principais alvos de "grupos de extermínio"3, e outros grupos despóticos.

Para isso, aplicamos como metodologia, na interpretação dos fatos, a leitura de notícias publicadas nos jornais locais e nos jornais nacionais e a apuração de publicações de usuários das redes sociais de internet, que forneciam informações muitas vezes ignoradas pela mídia convencional além de entrevistas realizadas com um padre e com moradores da Poligonal 1, no município de Vitória, onde frequentemente ocorrem incursões da polícia para coibir a atividade do tráfico de drogas. Tomando-se como ponto de partida o método dialético, a evolução da greve e da desestabilização social da ordem urbana na RMGV é interpretada à luz do senso crítico para reconstituir uma espécie de quebra-cabeça das estratégias postas em ação no tabuleiro do jogo político naquele momento. Indo além de um olhar restrito ao número de homicídios ou arrombamentos, por exemplo, apresenta-se uma leitura do que foi chamado de "crise da segurança", pelo conceito de urbicídio e seu aporte particular.

\section{URBICÍDIO}

O conceito de urbicídio está ligado ao discurso de novas guerras, que cada vez mais são travadas em terreno urbano (ver, em especial, COWARD, 2004, 2009; GRAHAM, 2004a, 2011; SHAW, 2004; FREGONESE, 2009; e SHARP, 2016). O termo, que se tornou usual durante a Guerra da Bósnia 1992-1995 como uma forma de enfocar a destruição generalizada e deliberada do ambiente urbano, foi tematizado em discussões originárias de programas de renovação urbana nos Estados Unidos, quando a cidade, como forma arquitetônica e como experiência sociopolítica, estava sob ataque do planejamento urbano no século XX.

\footnotetext{
${ }^{3}$ O uso da expressão "grupo de extermínio" deve ser considerado, ao longo de todo o texto, na condicional, pois o termo possui uma caracterização sociológica bem precisa: grupos formados durante a ditadura e que continuaram atuando depois do regime. Com exceção de uma declaração, citada mais à frente, em que o governo reconhece uma possível atuação de grupos de indivíduos em homicídios, empregando, de sua própria parte, a expressão "grupo de extermínio", pouco se sabe, além de imagens de vídeos amadores feitos por populares e por via de depoimentos de alguns entrevistados, sobre esses grupos.
} 
Embora o emprego original do termo urbicídio tenha como foco políticas urbanas de reestruturação em 1992, a questão da destruição generalizada de prédios na Bósnia durante a guerra civil foi tematizada por um grupo de arquitetos de Mostar sob outro foco, em uma publicação intitulada Mostar '92 - Urbicid.

Os autores de Mostar '92 - Urbicid apresentaram a destruição de edifícios em Mostar como um aspecto central da guerra em curso. Esta coleção de imagens e texto tentou demonstrar que a devastação do ambiente construído manifestada (embora não se limitando) na destruição das pontes, mesquitas e igrejas, lojas de departamento, blocos de apartamentos, edifícios públicos, hotéis e espaços públicos (como os parques) representou mais do que danos colaterais. Como tal, Mostar '92 - Urbicid tinha a intenção de chamar a atenção para a situação da arquitetura na ex-lugoslávia. [...]. Central a esta publicação, portanto, é a afirmação de que a destruição do ambiente construído tem um significado próprio, ao invés de ser acidental, ou uma característica secundária da violência genocida (ou "limpeza étnica") que caracterizou a Guerra da Bósnia (COWARD, 2009, p. 35-36, tradução nossa).

Martin Coward (2004, 2009), seguindo essa linha de raciocínio, foi o autor que desenvolveu o mais pertinente debate sobre esse tema anos depois, contestando algumas afirmações, tal como a de Martin Shaw (2004), de que urbicídio compreende uma forma de guerra que não pode ser separada de outras estratégias de aniquilação, como o genocídio, o etnocídio e o politicídio. Shaw argumenta que as cidades não sofrem sozinhas, pois sua miséria está vinculada à miséria mais ampla de sociedades inteiras: por isso o urbicídio precisa ser visto como um elemento amplo da guerra genocida travada na cidade. Segundo Coward, a destruição de formas específicas de urbanidade é perfeitamente compreendida como um exemplo de genocídio, como enfatiza Shaw. No entanto, o termo urbicídio implica uma distinção entre violência exercida sobre o ambiente construído e limpeza étnica conduzida por genocídio. Genocídio compreende práticas de extermínio de nações e grupos étnicos, enquanto urbicídio, embora se baseie numa semelhança lexical-conceitual com genocídio, enfoca, em sua própria razão, a destruição sistemática do ambiente construído.

Urbicídio, diz Coward (2009), consiste numa destruição que emprega uma forma distinta de violência que abarca "[...] a destruição de edifícios como condição de possibilidade de estar com os outros" (p. 14, tradução nossa). Em outros termos, "[...] os edifícios são destruídos porque eles são constitutivos da condição existencial conhecida como 'urbanidade'. 'Urbicídio' remete assim a um assalto a edifícios, a fim de destruir a urbanidade" (p. 15, tradução nossa). Nesse sentido, urbicídio consiste numa política de negação da cidade através da destruição urbana, colocada em marcha por regimes violentos, como o regime de nacionalismo étnico, que buscam a transformação da pluralidade em enclaves homogêneos.

Edifícios são destruídos não só porque pessoas vivem suas vidas a partir de uma instância física e são dependentes de toda a infraestrutura urbana, que configura, em sentido abrangente, o equipamento urbano para a vida. Edifícios são, antes de qualquer coisa, constitutivos da natureza da vida das pessoas na cidade em comunidade por isso, são alvejados em guerra urbana, com o intuito de destruir o ambiente de sobrevivência do inimigo, negando-lhe não a cidade propriamente, mas a condição existencial de estar na cidade e dela fazer parte (COWARD, 2009). 
A destruição do ambiente construído que constitui o substrato material de existência urbana é, portanto, a destruição das condições de possibilidade de heterogeneidade. O que está em jogo no urbicídio são, assim, as condições que possibilitam a heterogeneidade. Urbicídio, então, é a destruição de edifícios não pelo que eles representam individualmente (alvo militar, patrimônio cultural, metáfora conceitual), mas por seu papel como propiciador de condição favorável à existência do heterogêneo (COWARD, 2009, p. 39, tradução nossa).

Coward (2009) argumenta que edifícios são destruídos porque são constitutivos de uma fundamental espacialidade comum que é sempre compartilhada e expressão da heterogeneidade. Nesse ponto, a política urbicida pode levar ao apagamento do espaço comum e partilhado com o plural, em virtude da destruição da memória e de ambientes construídos que possibilitam a vida mútua das pessoas na cidade. O urbicídio, assim, não se restringe à expulsão das pessoas ou à destruição do ambiente, mas destrói as condições que propiciam o restabelecimento das forças heterogêneas antes existentes no lugar e de compartilhamento do mesmo espaço geográfico.

A Guerra da Bósnia, mais do que um assalto sustentado contra a população civil, foi um ataque a sua(s) cultura(s) e a seu ambiente urbano. Em meio à destruição de mesquitas, mas também de igrejas católicas e ortodoxas e de museus e bibliotecas, importantes símbolos culturais e de valor histórico, emerge a destruição de lugares banais, como cafés, cinemas, mercados, pontes, entre outros, "[...] em suma, lugares onde as pessoas se reúnem para viver a sua vida coletiva [...]"4 (ADAMS, 1993 apud COWARD, 2009, p. 8, tradução nossa). Tais espaços eram alvos de um programa de destruição de símbolos e infraestrutura urbana de uma sociedade multiétnica para alcançar homogeneidade no espaço. Nesse sentido, é claro que edifícios, simbólicos ou não, foram alvos de violência desproporcional para matar ou deslocar habitantes, mas, acima de tudo, para apagar qualquer vestígio histórico de uma sociedade que compartilhava havia séculos o mesmo lugar (COWARD, 2004, 2009).

Como Coward $(2004,2009)$ observa, a destruição deliberada de ambientes construídos e do patrimônio cultural, longe de ser um dos efeitos colaterais ou danos colaterais da guerra, era produto cuidadosamente produzido como parte da estratégia de guerra destinada a extinguir o elemento étnico do território; ao se destruírem as formas presentes e herdadas na paisagem arquitetônica na cidade, apagava-se qualquer resquício de ocupação anterior e compartilhada. Para tanto, destruir o registro histórico e a memória coletiva que caracterizava a coexistência da sociedade bósnia era fundamental como parte do programa urbicida.

A partir do exemplo da Bósnia, o urbicídio emprega, como se constatou, políticas de destruição urbana a partir de processo de militarização da sociedade e de identificação de territórios urbanos como "inimigos", que, ao serem alvejados, acentuam ou produzem antagonismo. Contudo, poderia a lógica do urbicídio não ser restrita a guerra deliberada, aplicando-se a episódios em "tempo de paz", em que as Forças Armadas e as polícias militares que detêm o monopólio dito "legítimo" da violência, ou grupos armados ilegais, como traficantes ou grupos de extermínio, ameaçam a integridade urbana da experiência de vida na cidade, aplicando doses de violência política de natureza urbicida? É esse aspecto do urbicídio que iremos explorar para compreender a "crise" da segurança pública no Espírito Santo a partir

\footnotetext{
${ }^{4}$ Adams, N. "Architecture as the target", 1993, in: Journal of the Society of Architectural Historians.
} 
de uma das características essenciais do urbicídio, a negação da vida na cidade por meio da violência política. Este aspecto é aqui focalizado como nexo fundamental de compreensão de práticas urbicidas. Com esse enfoque, sem perder de vista o aporte explicativo do urbicídio como um tipo de violência política orientada contra o espaço urbano de grupos específicos (embora nesse caso sem destruição física em grande escala da infraestrutura urbana), que dependem de um dado substrato, o artigo oferece um olhar sobre as especificidades do caso capixaba e de como o discurso do medo e a violência política, conduzida, sobretudo, contra pobres e negros e seus espaços, foi manipulado para provocar desordem e pânico na região metropolitana, anulando, assim, o espaço urbano comum de convivência ${ }^{5}$.

\section{ELEMENTOS PARA COMPREENDER O ESTADO DE EXCEÇÃO NEOLIBERAL E A GREVE DA POLÍCIA MILITAR NO ESPÍRITO SANTO}

O exemplo do Espírito Santo, um pequeno estado da Federação, com apenas quatro milhões de habitantes, ganhou destaque no início do mês de fevereiro de 2017 em todos os noticiários nacionais por ocasião da paralisação de sua polícia militar $^{6}$. A greve que se iniciou em 4 de fevereiro e teve fim apenas em 25 de fevereiro, mergulhou o estado, em especial a cidade de Vitória e sua região metropolitana, numa onda de "caos" e violência". Os militares paralisaram suas atividades reivindicando a correção de seus salários pela inflação do período e pediam os valores retroativos ao ano de 2010 - período a partir do qual o governo passou a não mais conceder essa correção. Além dessa e de outras reivindicações, pediam também auxílio-alimentação e adicionais de periculosidade e insalubridade. Alegavam, igualmente, o sucateamento da frota de automóveis, além de compromissos (ou promessas) que lhes foram feitos e não honrados pelo Governo do Estado ${ }^{8}$.

A estratégia adotada pelos policiais militares para reivindicar as perdas salarias, já que não podem fazer greve, conforme prevê o artigo 142, inciso IV da Constituição Federal de 1988, foi usar os familiares, em particular as esposas deles, para bloquear a saída das viaturas da polícia que se encontravam estacionadas nos quartéis. Desse modo, a paralisação ganhou força na madrugada de sábado, 4 de fevereiro, com protestos dos familiares nas portas dos quartéis, bloqueando a saída

\footnotetext{
5 Preferimos, por hora, o uso do termo "urbano comum" ao invés de "público", pois aquele fornece, a nosso ver, a possibilidade de desafiar a violência do Estado que se arroga a "defesa do público", mas, nesse caso, contra a própria sociedade. Para uma leitura mais aprofundada sobre o "comum" nessa linha de raciocínio pode-se consultar Dardot e Laval (2017).

6 Os policiais militares no Brasil de acordo com o inciso IV, do §3º, do art. 142, da legislação de 1988 , não podem se sindicalizar e realizar greve, como rege o texto da Constituição Federal: "IV - "ao militar são proibidas a sindicalização e a greve;". Desse modo, eles são obrigados a usar artifícios para fazer greve e tomam muitas vezes decisões extremas, indo para o tudo ou nada, para impor um direito não reconhecido em lei.

7 É importante mencionar que havia, ao invés de pura e simples desordem, uma ordem adjacente às disputas políticas e ações de limpeza efetuadas por grupos de extermínio, ou pelo tráfico, marcada por disputas por territórios e interesses encobertos pela aparente desordem e situação caótica.

8 Para ver em detalhes as reivindicações da Polícia Militar do Espírito Santo, segundo noticiou a mídia, pode-se consultar a matéria do jornal $A$ Gazeta, O que de fato reivindicam os policiais militares do Espírito Santo?, publicada em 9 de fevereiro de 2017 no seguinte endereço eletrônico (https://www.gazetaonline.com.br).
} 
das viaturas e dos militares para as cidades da RMGV e para as cidades de Linhares, Aracruz, Colatina e Piúma, assim, o movimento se expandiu rapidamente para outras cidades, colocando a maior parte do efetivo da polícia fora das ruas ${ }^{9}$.

Com o prolongamento da greve e com a adoção de medidas administrativas que determinavam abertura de inquérito judicial contra os policiais grevistas, os manifestantes passaram a solicitar também a anistia geral dos militares contra toda e quaisquer sanções administrativas e judiciais que lhes pudessem ser impostas aos policiais e, no último caso, aos familiares. Estes permaneciam nas portas dos quartéis, "impedindo" aparentemente a saída das patrulhas dos policiais. A negociação entre governo e os familiares, representantes dos militares em greve, transformou-se num verdadeiro braço de ferro, marcado por reviravoltas e intimidações, tendo fim somente em 25 de fevereiro, sem reajuste salarial para a categoria, mas com um acordo em que o governo se comprometeu em desistir das ações judiciais contra as associações dos policiais e a maior parte dos grevistas (embora punições administrativas e prisões preventivas seguidas de processos judiciais tenham sido efetuadas $)^{10}$ e formar uma comissão para regulamentar a carga horária dos policiais.

Durante a paralisação dos policiais militares o Espírito Santo registrou 219 homicídios dolosos confirmados, e o número pode ser ainda maior, conforme especulam entidades dos direitos humanos e movimentos sociais. Segundo dados do Sindipol/ES, apurados pelo jornal ES Hoje, o mês de fevereiro de 2017 registrou 229 homicídios, contra 122 do mês de fevereiro de 201611. Entre os mortos, em geral, estariam, supostamente, segundo as fontes de jornais, "usuários de drogas", "pessoas com antecedentes criminais" e "vítimas de balas perdidas", em sua maior parte pessoas negras e moradores de bairros populares. Por conta do aumento vertiginoso do número de homicídios o Departamento Médico Legal (DML) de Vitória ficou com suas geladeiras cheias e com inúmeros corpos espalhados por seus corredores. Cenas de corpos abandonados no asfalto ou amontoados dentro de ambulâncias também foram registradas, por meio de câmeras de smartphones, cujos vídeos foram compartilhados na internet. Além das mortes, houve aumento escalonar de veículos roubados e de lojas saqueadas nesse período, com prejuízos de milhões de reais ao comércio. Cenas de saques e execuções sumárias também foram registradas por celulares e divulgadas na rede. Em razão da insegurança,

\footnotetext{
${ }_{9}^{9}$ Para mais detalhes ver Miguel Caballero, Vitória tem noite de 'cidade fantasma' e amanhece sem ônibus, 7 de fevereiro de 2017, jornal O Globo (http://oglobo.globo.com/brasil).

10 Os tribunais decretaram logo após o fim da paralisação dos policiais a prisão do tenente-coronel Carlos Alberto Foresti, do ex-deputado federal Capitão Assumção, do soldado Maxson Luiz da Conceição e do sargento Aurélio Robson Fonseca da Silva, todos eles acusados de incitar e liderar o movimento grevista, além de outros envolvidos, presos preventivamente. Para consultar a lista completa e com mais detalhes dos policiais e familiares acusados de incitar a greve e que foram acusados de integrar organização criminosa, ver a reportagem de Vilmara Fernandes, Greve da PM: 10 militares sentam no banco dos réus, de 16 de maio de 2018, para A Gazeta (<https://www.gazetaonline.com.br/>). Sobre a ligação do movimento grevista com interesses políticos, um relatório parcial da Polícia Federal diria que aliados no Estado do então presidente Jair Bolsonaro, na época deputado federal, entre eles o Capitão Assumção e o deputado federal Carlos Manato, além de assessores de Bolsonaro, citados no documento, teriam impulsionado a paralisação dos policiais. Para mais detalhes ver reportagem da Folha Vitória, Aliados de Bolsonaro teriam impulsionado o motim de PMs no Espírito Santo, publicada em 25 de fevereiro de 2017 no referido portal (<http://m.folhavitoria.com.br $>$ ). Sobre a anistia concedida pelo governador Renato Casagrande (PSB - pleito 2019-2022) aos mais de 2.600 policiais envolvidos com a greve, beneficiando inclusive 23 policiais expulsos, ver a matéria de Caique Verli, Deputados Estaduais aprovam a anistia a PMs grevistas, de 16 de janeiro de 2019 no jornal $A$ Gazeta (<http://www.gazetaonline.com.br>). Sobre as criticas do ex-governador Paulo Hartung a anistia concedida por seu sucessor, ver Hartung sobre a anistia a PMs: "Decisão política grave e irresponsável", de 16 de janeiro de 2019 no jornal $A$ Gazeta (<http://www.gazetaonline.com.br>).

11 Ver a reportagem de Danieleh Coutinho: Sindipol: em 2017 o Espírito Santo registrou 222 mortes a mais do que no ano anterior, publicada em 2 de janeiro de 2018 no jornal ES Hoje (http://eshoje.com.br).
} 
escolas e postos de saúde deixaram de funcionar, e inúmeras lojas baixaram as portas: um cenário de ruas abandonadas, de medo e pânico produzido na região metropolitana durante os dias em que houve mais violência ${ }^{12}$.

Tudo isso deveria ser explicado como um simples episódio a que estão sujeitas as cidades e regiões metropolitanas do país, que pode se repetir (como ocorreu logo depois, no fim do mês de dezembro de 2017 no Rio Grande do Norte, com a paralisação da Polícia Militar daquele Estado), ou deve ser analisado de forma mais estrutural, como parte da lógica de militarização das cidades e de aumento da violência urbana? A partir da perspectiva traçada aqui, o episódio é mais bem ilustrado pelas lógicas de militarização em transcurso na cidade, pela generalização do medo e da violência, mas também pela operacionalização dos discursos que organizam e massificam a violência cotidiana na cidade. Desse ponto de vista questiona-se, em primeiro plano, se a proliferação da violência seria apenas causa da paralisação da polícia ou se por trás da onda de violência não estaria em ação a operacionalização da violência política como modelo de insurgência do discurso e das práticas de policiais militares. Neste último caso, deve-se considerar a violência da polícia militar como interface de uma complexa construção social. Ela tem a ver, em parte, com as relações de dominação social e é muito impulsionada pelo Estado, pelas leis discricionárias e pelas próprias definições de "crime" que tem definições variáveis, em função do período e das leis votadas nos parlamentos (conforme os diferentes códigos penais), que são cada vez mais punitivas, em relação, particularmente no caso do Brasil, aos crimes contra o patrimônio e ao caso do consumo de drogas ilegais. Por outro lado, é verdade, há uma violência cotidiana, familiar, que tem a ver com o ambiente social, mas também com a regulação das "coisas" pela força sem a mediação social necessária que deveria ser o papel do Estado. Portanto, a questão é complexa e a polícia militar opera sob os auspícios de uma organização hierárquica herdada do Exército. Ela não é uma "polícia de paz", mas uma polícia que usa a força de contenção e repressão, mesmo se em vários casos exerce um papel de presença do Estado junto às populações dos bairros populares, realizando assistência de diversas ordens.

Em função de sua complexidade, a análise do aumento da violência durante a greve da Polícia Militar não deve ficar restrita ao discurso sobre o "bandido", noção ambígua, recorrente e que tem a pretensão de tudo explicar e justificar. O enfoque deve se centrar na análise dos agentes, dos atores e dos sujeitos que compõem as classes sociais, por isso o debate melhor qualificado deve optar por desnudar as relações sociais ao invés de se apegar a elementos isolados e episódicos. Por essa nuança, melhor tratar o problema da "crise" de fevereiro de 2017 como uma causa exponencial da violência estrutural e buscar desvelar as incógnitas e múltiplas variáveis do fenômeno como parte do processo de uma cadeia estrutural que tenciona a sociedade. Essa violência estrutural é recoberta no Brasil hoje pelos inúmeros clichês de senso comum, como "bandido bom é bandido morto", entre tantos outros de origem neofacista. Nós aqui nos limitaremos a analisar os aspectos dos efeitos políticos ou de uma geopolítica urbana das determinações, ações e

\footnotetext{
12 Sobre a onda de violência e a paralisação da vida cotidiana na RMGV, pode-se consultar uma série de reportagens sobre o tema, entre elas, a de Miguel Caballero, intitulada Vitória tem noite de 'cidade fantasma' e amanhece sem ônibus, para O Globo (http://oglobo.globo.com/brasil), publicada em 07 de fevereiro de 2017. Para uma leitura dos últimos dados atualizados do número de mortes contabilizados e o andamento das investigações, consultados pelos autores, pode-se verificar a reportagem de Sullivan Silva e Raquel Lopes, Greve da PM: seis meses depois, publicada em 3 de agosto de 2017, disponível no site do jornal $A$ Gazeta (http://www.gazetaonline.com.br) e a matéria de Folha Vitória, intitulada Mortes durante greve da PM ainda continuam sem esclarecimento, publicada em 1 de fevereiro de 2018, disponível no endereço eletrônico do portal capixaba (https://novo.folhavitoria.com.br).
} 
inações do Estado e sua força armada sobre a sociedade tendo como consequência o urbicídio.

Assim, mais substancial para entender a violência urbana do nosso cotidiano do que pautar a ação da violência em determinados episódios (como assaltos, roubos ou homicídios) é analisar as determinações e o conjunto do fenômeno da militarização e da violência política na cidade, que no caso particular da greve dos policiais catalisou momentaneamente o colapso do modelo de segurança fundado no combate "à sociedade" e com policiais mal remunerados, com formação e preparação equivocadas, o que levou ao agenciamento de uma aparente desordem urbana, induzindo ao urbicídio tal como evocamos. Diante de tais aspectos, a violência do período da greve não se deu somente em virtude da retirada das patrulhas policiais da rua, mas, sobretudo por conta do consequente desequilíbrio de "forças militares", compostas por grupos armados legais (como a polícia) e ilegais (como o tráfico de drogas e outros grupos indeterminados) no cenário urbano do estado, em especial da RMGV, que passaram a atuar com mais "liberdade" e com maior margem de impunidade durante o período da greve.

Foi nesse cenário, que a paralisação da Polícia Militar demonstrou, por seu turno, o desenvolvimento ou aprofundamento de práticas de uma tendência urbicida, mais consolidada no Brasil em cidades como o Rio de Janeiro, mas que, na RMGV, talvez, pela primeira vez, mostrou-se como modo operante de violência urbana de intrínseca característica política. Nesse sentido, não é nosso objetivo analisar o período da greve dos policiais militares episódio por episódio, que marcaram as negociações entre as partes de uma longa novela que se desenvolveu entre o Governo do Estado do Espírito Santo e os policiais e seus familiares, mas enumerar e compreender, a partir dos antecedentes mais recentes, possíveis de vasculhar neste momento, os fatores que desencadearam a greve a partir do cenário atual da política de gestão do governador Paulo Hartung, com cortes em serviços básicos e, principalmente, com uma profunda política de arrocho salarial. Partindo de tal apontamento, é nosso interesse analisar, na sequência, os efeitos da paralisação e da violência no cotidiano da população e as implicações da generalização da sensação de medo na cidade, que caracterizaram um conjunto de práticas urbicidas durante aqueles dias como uma forma de negação da vida urbana e se inscrevendo numa lógica de violência institucional e estrutural como consequência de um economicismo sacrificial que submete a sociedade aos ditames neoliberais.

Considerando o elemento preliminar, é possível enxergar na greve dos policiais um dos efeitos da política de "austeridade" do Governo do Espírito Santo na precarização dos serviços. Esta medida tem promovido uma crise social e está diretamente relacionada a uma política de estado de exceção, justificada, por exemplo, por meio do emprego do discurso de que sacrifícios são necessários diante da "crise econômica" e do aumento de desemprego. Suas implicações na política de segurança pública tornam o aparelho estatal mais opressivo e operante sob padrões excepcionais de violência política contra as classes mais vulneráveis ao monopólio da violência exercida pelo Estado. No Brasil, em particular, é possível correlacionar, no caso da segurança pública, o viés antidemocrático de mediação dos conflitos como consequência de uma sociedade profundamente desigual, que caracteriza, de algum modo, o estado de exceção como prática cotidiana de opressão que vigora no Brasil para as classes dominadas desde a colonização. Embora em vigor, a Constituição de 1988, que em tese garante aos brasileiros direitos plenos e inalienáveis, é escamoteada ainda hoje no limiar histórico de desenvolvimento de práticas de controle das massas, em que o monopólio do uso de violência pelo 
Estado - por ausência ou presença - passa a operar por padrões de violência política, bem particulares, direcionados contra as classes populares, que têm seus direitos sociais mais básicos ignorados pelo ordenamento político, que institui de uma forma aparentemente mais "suave" o estado de exceção - sob a aparência de um jogo "democrático" - como a norma política de perseguição e punição a um grupo específico, no caso do Brasil, moradores de bairros populares e pessoas majoritariamente negras e pobres.

Essa transformação da exceção em regra como característica do estado de exceção, observada em primeiro lugar por Walter Benjamin, mas melhor desenvolvida pelo filósofo italiano Giorgio Agamben (2014), demonstra a transformação do estado de exceção em regra do Estado contemporâneo. Nele, o totalitarismo moderno instauraria o estado de emergência permanente, normalizando o estado de exceção e autorizando, por esse viés, a permanência de medidas excepcionais. Tal como desde suas origens, desde o direito romano, a emergência do estado de exceção seria declarada formalmente, na contemporaneidade, em situações de crise, que podem ser crises econômicas e políticas, ou, no nosso caso em particular, de segurança, que espelham no nosso tempo, em alguma medida, as condicionantes de situações de guerra de outrora. Por isso se recorre ainda hoje à metáfora militar para estabelecer analogias de guerra com a economia ou em demais situações, de suposta insegurança, como é comum no Brasil para naturalizar e transformar execuções sumárias em políticas de segurança.

Atualmente é impossível não notar, a partir das recentes políticas regressivas de cunho neoliberal do governo de Michel Temer e sua continuidade no governo Bolsonaro, o engendramento do estado de exceção. Como destaca Rafael Valim (2017, p. 34, itálicos do original), "[...] o estado de exceção é uma exigência do atual modelo de dominação neoliberal. É o meio pelo qual se neutraliza a prática democrática e se reconfiguram, de modo silencioso, os regimes políticos em escala universal". No Brasil a estratégia inclui a adoção de uma série de medidas: um programa de austeridade seletivo, com duração de vinte anos, aprovado por meio de uma emenda constitucional (Emenda Constitucional n. 95/2016) que sacrifica as despesas sociais para pagar as despesas com a dívida pública, e outras leis que resultaram em instabilidade na ordem econômica; a alteração da Lei n. 13.365/2016, que acaba com a exclusividade da Petrobras como operadora do Pré-sal; a aprovação da Reforma Trabalhista (n. 13.467/2017) e a proposta de Reforma da Previdência Social, que resultam em escandalosos retrocessos sociais. Medidas excepcionais semelhantes, marcadas por cortes e redução de investimentos em serviços essenciais encontraram um terreno fértil no governo Paulo Hartung para desenvolver-se em silêncio, como se o Espírito Santo fosse uma espécie de laboratório para o restante do país quando os olhares críticos concentravam-se em Brasília, São Paulo e Rio de Janeiro.

Partindo dos vínculos entre estado de exceção e o neoliberalismo, aplicados no Brasil e no Espírito Santo, podemos, agora, em primeiro plano, desnudar a 
política neoliberal implementada pela gestão Paulo Hartung (2015-2018) ${ }^{13}$, apelidado pelos capixabas de "Imperador", por suas posturas irredutíveis e autoritárias. É de conhecimento geral que o governador investiu pesado na assessoria de comunicação para apresentar como palatável à população o seu pacote de "ajuste fiscal", posto em prática desde a sua volta ao Palácio Anchieta, em 2015. O marketing de Paulo Hartung foi eficiente durante algum tempo em apresentar o corte de investimentos essenciais na área da saúde, educação e segurança como uma política de controle dos gastos para honrar os compromissos do governo durante a crise econômica que atravessa o país.

Enquanto governadores de outros estados tinham dificuldade em pagar os salários do funcionalismo público em dia, Paulo Hartung aparecia na TV e comparecia a eventos empresariais para apresentar, em gráficos bem ilustrados, sua política supostamente inquestionável de responsabilidade administrativa, que expressava, ao seu modo de pensar, que o governo não pode gastar mais do que arrecada. Com tal discurso, o governador ainda pôde explorar os dados positivos da maior redução da taxa de homicídios dos últimos 28 anos ${ }^{14}$, durante o segundo ano de seu governo, num estado que figurava havia muito tempo entre os primeiros colocados no ranking nacional das taxas de homicídios.

O governo Hartung maquiou a precarização dos serviços públicos, entre eles a segurança: a prova é que ele permitiu a redução, o que foi uma das primeiras polêmicas do seu governo, do consumo de combustível das viaturas das polícias Civil e Militar, o que ocasionou em um menor patrulhamento das ruas, aspecto esse que não foi abordado pelos veículos de comunicação. Essa evidência bem como uma série de outras polêmicas que envolviam a redução ou precarização dos serviços públicos ofertados em outras áreas também não foi debatida pela mídia dominante local. Assim, Paulo Hartung seguiu como o "representante do mercado" e o Espírito Santo como um laboratório - caracterizado pela política de "austeridade" implantada em terras capixabas - das políticas neoliberais em implementação no Brasil.

Foi diante dessas circunstâncias que Paulo Hartung se manteve irredutível e não aceitou negociar nenhum tipo de reajuste salarial com os policiais. Quem cedeu a pressão, ao final, foi de fato a polícia, que após varias ameaças do governo foi derrotada. Paulo Hartung, embora tenha saído com a imagem desgastada, mantevese inflexível, em parte, aparentemente, para sustentar sua imagem; ceder à reivindicação de reajuste salarial dos policiais significaria ter que negociar com outras categorias e abrir mão do discurso midiático institucionalizado de que o

\footnotetext{
13 Nosso enfoque na política administrativa de Paulo Hartung na gestão 2015-2018 é fundado (além da percepção particular dos autores) nas reportagens do Século Diário, em particular na matéria intitulada Do céu ao inferno, publicada em 8 de fevereiro de 2017 pelo portal capixaba (http://seculodiario.com.br); na reportagem do portal Brasil 247, intitulada Nassif: trava-se no ES a primeira grande batalha de desmonte do Estado brasileiro, publicada no dia 13 de fevereiro e disponível no endereço eletrônico do portal (http://www.brasil247.com); na matéria de Luis Nassif, Xadrez de Paulo Hartung, fiscalista que a Globo inventou, por Luis Nassif, que foi publicada no dia 23 de novembro de 2017 e que se encontra disponível no portal do Jornal GGN (https://jornalggn.com.br); no texto de Tyago Hoffmann, ex-secretário da Casa Civil durante o governo de Renato Casagrande (2011-2014), intitulado O desmonte do Espírito Santo, publicado em O Globo no dia 23 de fevereiro e disponível no site do portal (http://www.//oglobo.globo.com); além do texto de Vitor Vogas, que de forma surpreendente conseguiu sair do casulo e abriu espaço para o debate na grande mídia capixaba, que frequentemente tem blindado Paulo Hartung, ao publicar Problemas no Paraíso, no dia 11 de fevereiro de 2017, no portal de notícias A Gazeta, no seguinte endereço eletrônico (http://novo.gazetaonline.com.br).

14 O Espírito Santo encerrou o ano de 2016 com a menor taxa de homicídios dos últimos 28 anos. Entre 2009 e 2016 a taxa de homicídios caiu pela metade, contabilizando números comemorados pelo governo de 29,7 mortes por cem mil habitantes. No entanto, esses números devem ser relativizados, tendo em vista que a redução das taxas de homicídios foi acompanhada de uma política de aprisionamento em massa no país inteiro. Para uma análise do decênio 2001-2010 para o caso do Espírito Santo pode-se consultar Zanotelli et al (2011).
} 
governo não tinha recursos e que cortes eram necessários para manter o funcionamento da máquina pública. O governo Paulo Hartung para tal tratou a reivindicação dos policiais pelo viés da criminalização do movimento.

Segundo o jornalista Luis Nassif, o Espírito Santo foi o palco da primeira grande batalha de desmonte do Estado brasileiro, um laboratório, em outros termos, em que a política econômica de Paulo Hartung (MDB) seguiu apenas o mainstream do Congresso, da mídia e do ex-governo Michel Temer (também do MDB), que usava da imagem do governante responsável para desestruturar o aparelho estatal e assim invocar a crise econômica para justificar o desmonte do Estado. Velhos chavões bem aceitos pelo meio empresarial, tais como gestão, qualidade, eficiência, inovação e responsabilidade fiscal, eram empregados pelo governo, que usava o mesmo marketing da gestão privada na administração pública, uma fórmula questionável, mas convincente para o grande público.

$\mathrm{Na}$ verdade, o que fez Hartung foi uma política gestora bem organizada de precarização dos serviços públicos e dos direitos sociais; uma política de incentivos à atração de empresas sem avaliação custo-benefício e transparência no processo de licitação e contratação; além da ausência de diálogo com os setores sociais e servidores públicos, tratados como inimigos do Estado, mediante a adoção de políticas governamentais draconianas na administração pública. Em linhas gerais, a política no "Hartunguistão", outro apelido, agora apregoado ao Estado do Espírito Santo sob a tutela de Hartung, não passava de um esquema bem costurado de arrocho salarial dos servidores acoplada a uma política de subsídios visando atrair empresas para o estado com base em análises frágeis da relação custo-benefício, acobertadas por um poderoso trabalho midiático sobre a imagem de Paulo Hartung como gestor público.

Foi, em parte, esse modelo de gestão que abriu precedente para a crise da segurança pública no estado, em que de um lado tínhamos uma categoria insatisfeita e afeita ao enfrentamento, e do outro lado, o governador Paulo Hartung, ambos colocando em risco a sociedade capixaba, não importando o custo para atender seus objetivos. Mas de fato, no que tange à violência urbana daqueles dias, além dos números, o que ocorreu de substancial para caracterizarmos, ou melhor, identificarmos uma modalidade de urbicídio? Enquanto a polícia permanecia oficialmente paralisada e parte significativa de seu efetivo havia se aquartelado nos quartéis, uma onda de saques e arrastões acontecia na RMGV e também no interior do estado, grupos ilegais (traficantes ou não) disputavam territórios entre si e toques de recolher eram impostos em algumas regiões da RMGV por esses grupos, colocando a região metropolitana em paralisia, sem transporte público e com a maior parte dos serviços indisponíveis à população. Muitos moradores tiveram inclusive dificuldade durante a greve para repor os mantimentos, uma vez que um número significativo de supermercados e armazéns também fechou.

No domingo, 5 de fevereiro, dia em que de fato os capixabas se deram conta que haviam sido abandonados, não demorou muito, mensagens com relatos e vídeos filmados por celulares começaram a circular mostrando arrastões em shopping centers e cenas de arrombamento em todo o estado, diga-se de passagem que muitos saques foram efetivados por setores variados da população que se aproveitaram da ocasião. Não demorou, vídeos de corpos abandonados pelas ruas, em especial da RMGV, ocuparam os compartilhamentos dos usuários de redes sociais, com destaque especial para as imagens de corpos empilhados no DML, que teve a sua capacidade excedida. O que foi anunciado como uma "guerra de todos contra todos" com a ausência de autoridade logo se tornou uma caçada de homens 
armados, alguns fardados, contra supostos infratores e a quem se aventurou pelas ruas ousando não respeitar o toque de recolher imposto, não se sabia, às vezes, por quem exatamente ${ }^{15}$.

Com o decorrer dos dias, vídeos de execuções sumárias e de pessoas amarradas em postes ocuparam mais espaço na caixa de armazenamento dos celulares: em um deles, no bairro Planalto Serrano, em Serra, o município mais populoso da região metropolitana, uma mulher, de forma surpreendente, filmou e compartilhou a execução de um homem retratado no vídeo como suposto malfeitor. No vídeo, ela filma toda a ação do seu apartamento e vibra com os disparos, sem deixar de comentar: "Acabou, ah que legal. Caraca meu, esse aí foi pro saco gente. Matar mesmo, massa...". Esse vídeo, e tantos outros que circularam pelas redes sociais, em particular na página de Facebook do Serra Noticiário, uma página independente de entretenimento e de conteúdo variado sobre o dia a dia dos capixabas, com os usuários enviando inúmeros vídeos para o canal, passou a fazer a melhor cobertura em "tempo real" do que ocorria na rua. Essa cena demonstra, como invocado pelo psiquiatra e filósofo, militante anticolonialista, Francis Fanon ([1952] 2001), que em países então chamados de Terceiro Mundo não se identificam as estruturas de classe e de opressão como inimigas, mas o outro, o vizinho, o igual, uma espécie de darwinismo social. Por outro lado, parece que, quando não há mais uma possível repressão, certos indivíduos e setores se "liberam" para fazer tudo e qualquer coisa, não havendo, nesses casos, limite e autocensura na violência contra o outro. E isso se conecta com a situação de desmoralização das instituições do Estado, que é governado contra a sociedade, e do ancestral apartheid social e da banalização do "mal" no Brasil. As pessoas muitas vezes se colocam contra seus próprios interesses, uma espécie de "coerção consentida" ou de "escravidão voluntária", contribuindo, como os próprios policiais que em sua imensa maioria são saídos das classes populares, para que se dominem ainda mais as classes subalternas.

Em tais vídeos é possível constatar ação de grupos de extermínio, alguns deles com aparente envolvimento de policiais. Grupos armados circulando pelas ruas e fazendo a segurança dos bairros foram filmados em várias localidades da RMGV, com armas expostas ${ }^{16}$. Em um vídeo que circulou pela internet uma pessoa, morador de um bairro do município de Serra, filmou da greta da janela de sua casa a ação de pessoas com uniforme da Polícia Militar que, segundo ele, fariam parte de um grupo de extermínio da polícia. Segundo diz a pessoa no vídeo, o grupo chegou ao bairro onde reside mandando os moradores entrarem em suas casas e dizendo que iria matar todo mundo. No vídeo os supostos policiais estão em três veículos sem identificação e com armas em punho. É possível visualizar três homens, dois deles fardados e um terceiro com camisa laranja.

O Governo do Estado chegou a admitir o possível envolvimento de grupos de extermínio e a participação de policiais em assassinatos com o objetivo de agravar

\footnotetext{
15 Inúmeros vídeos de pessoas assassinadas e reféns da violência em suas casas, com medo de sair para ir ao trabalho ou à escola, circularam e foram compartilhados na internet em aplicativos de redes sociais como o Whatsapp. Ao analisar esse material, chegamos à constatação que nem sempre os moradores tinham consciência de qual era a norma vigente dentro daquela situação de aparente desordem. Os vídeos a que tivemos acesso, ainda que às vezes de forma um pouco apelativa do discurso do medo, mostram o receio de sair de casa e estar desrespeitando alguma regra imposta, direta ou indiretamente, por grupos atuantes naquele momento e numa dada região.

${ }^{16}$ Embora a maior parte da polícia do estado tenha aderido à grave, muitos grevistas não deixaram, contudo, de trabalhar na segurança privada de lojas e empresas durante o período. Na verdade, houve aumento da demanda por segurança privada e um aumento significativo dos preços pelos serviços de segurança durante a greve. Ao que tudo indica, as empresas privadas de segurança e pessoas que prestam serviços nessa área foram os únicos que lucraram durante a greve da Polícia Militar no estado.
} 
ainda mais a crise no estado ${ }^{17}$. Segundo a entrevista da advogada criminalista Danielly Penedo Wandekoken para o jornal A Gazeta, de 3 de agosto de 2017, os policiais aproveitaram a greve e a ausência de ordem por conta de sua própria paralisação para fazer uma espécie de "limpeza" social dos indivíduos com suposta "passagem pela polícia", revelando o absurdo de se justificar a morte de outrem por um fichamento na polícia. Do total de adolescentes que morreram durante a greve a mídia hegemônica capixaba especula, embora com informações contraditórias e às vezes duvidosas, que a maioria teria algum envolvimento anterior por atos de infração relacionados a drogas, mas de concreto nada se sabe ${ }^{18}$. A única coisa que se pode afirmar a esse respeito é que os homicídios concentraram-se em bairros populares (como indicam alguns dados levantados a partir das ocorrências registradas na DHPP que foram disponibilizados pela AOB-ES) e que os alvos preferenciais foram jovens negros (como se pode verificar nos vídeos que circularam pela internet, em especial de corpos no DML, quase todos negros).

A ação de extermínio deu-se em bairros populares e, em muitos casos, com forte presença do tráfico, fora dos holofotes da mídia. O modo operante da ação de tais grupos pode ser um pouco elucidado a partir do depoimento de um líder católico, militante há mais de 20 anos em bairros da periferia onde há forte presença de grupos que operam no mercado ilegal de drogas. No início dos distúrbios o pároco escutou um barulho. Ao sair de casa para constatar o que estava ocorrendo, verificou pouco adiante de sua residência dois corpos fuzilados. Segundo seu relato, durante a paralisação da polícia havia grupos distintos atuando no bairro onde mora: um deles, o do tráfico, atuava de forma mais contida, já que há dois anos, segundo suas próprias palavras, as quadrilhas tinham-se apaziguado, evitando, portanto, o confronto entre elas para resolver suas diferenças e disputas internas. Para ele,

quem executou no domingo [dia 05 de fevereiro, dois rapazes] à noite, que começou a chacina não foi de lá, porque o modus operandi não era do tráfico. As pessoas que foram para lá [estavam] uniformizadas. Calça preta, blusa preta e toca. Armas de calibre grosso, não foram os meninos de chinelo, de bermuda, não foi, não foi [o tráfico]. Foi com o intuito de criar o caos na região mesmo ${ }^{19}$.

É curioso notar que em outros bairros de Vitória onde há forte presença do tráfico de drogas ilícitas, como São Benedito e adjacências, lugares esses que por

\footnotetext{
17 Ver a matéria de Vitor Vogas, Governo investiga possível atuação de grupos de extermínio, para o jornal $A$ Gazeta, publicada em 11 de fevereiro de 2017 e disponível no site do portal (http://novo.gazetaonline.com.br).

${ }_{18}$ Ver a matéria de Natalia Bourguignon, Greve da PM: advogada diz que adolescentes foram vítimas de extermínio, para o jornal A Gazeta, publicada em 3 de agosto de 2017 e disponível no site do portal (http://novo.gazetaonline.com.br). Sobre o andamento das investigações, a reportagem de Viviane Machado, Crise da segurança faz 1 ano e onda de homicídios volta a crescer no ES, 5 de fevereiro de 2018, para o G1 Globo (https://g1.globo.com), fornece um panorama geral e contraditório da situação de andamento das investigações: segundo ela, em julho de 2017, o Ministério Público do Espírito Santo (MP-ES) divulgou que fez mais de 700 denúncias de crimes ocorridos durante a greve. Entre os crimes estavam homicídios, latrocínios, incêndios a ônibus, furtos, roubos, ameaçadas etc. Só de homicídios o MP-ES identificou 210 (o número de homicídios mencionados nas reportagens, mesmo quando citadas "fontes oficiais", varia, conforme observamos normalmente entre 209 e 2019 homicídios - uma verdadeira incógnita, para não dizer confusão). Destes, segundo a consulta feita pela reportagem, 153 ainda estavam em fase de investigação. Contudo, o MP-ES não informou a situação das investigações dos homicídios. O então secretário de Segurança Pública na época, André Garcia, por sua vez, afirmou que pelo menos $60 \%$ dos inquéritos já foram solucionados. Porém, do nosso ponto de vista, parece haver uma grande dificuldade no andamento das investigações e um receio ainda maior por parte das instituições responsáveis de elucidar o andamento das investigações e de divulgar números mais concretos.

${ }^{19}$ Entrevista informal com líder católico em 26 de setembro de 2017. Não mencionamos o nome do entrevistado em virtude do respeito ao anonimato.
} 
inúmeras vezes tiveram confrontos violentos entre as quadrilhas, tivemos poucos registros de saques e homicídios durante a greve. Segundo depoimento de entrevistados que residem na região, embora houvesse receio da população de grande mortalidade no território durante a greve, isto não se confirmou, porque o tráfico local havia feito um acordo bem antes da paralisação para evitar conflitos e resolver suas diferenças na mesa de negociação. De outro modo, também segundo os entrevistados, grupos de tráfico de drogas ilícitas que atuam no município de Serra, por estarem em conflito, não se deslocaram para ameaçar os traficantes do bairro São Benedito, de Vitória ${ }^{20}$. Contudo, é importante dizer que nessa região de Vitória, aparentemente, não houve atuação de grupos de extermínio, muito provavelmente por causa da proximidade com $\circ 1^{\circ}$ Batalhão de Polícia Militar do Estado, situado a poucos metros, lugar onde as esposas dos policiais permaneciam na frente do quartel, em protesto.

Se, por um lado, durante os primeiros dias da greve, o alto índice de mortalidade aliado à ausência de patrulhamento da polícia serviu para espalhar insegurança e violência de todo tipo, nos últimos dias da greve da Polícia Militar o modo operante daqueles que agiam para espalhar o terror se concentrou no ataque aos ônibus do sistema de transporte público intermunicipal (Transcol). Os três primeiros incêndios ocorreram no segundo dia de paralisação, 5 de fevereiro, um domingo, todos em Manguinhos, bairro litorâneo de Serra, muito provavelmente para chamar atenção da opinião pública. Por se tratar de um bairro sem registro de atuação territorial do tráfico e com pouca concentração de residências, é plausível endossar que tais atos não passavam de uma ação midiática para ser consumida pelas lentes das câmeras e causar impacto, para amplificar a sensação de medo na população. Sem dúvida, um bom lugar para incendiar ônibus sem ser notado, agilizar a fuga e ainda assim impressionar a opinião pública da região metropolitana. Contudo, os incêndios foram deixados de lado, temporariamente, retornando a cena apenas na segunda semana de paralisação, com novas notícias de incêndios, ocorrendo agora de forma sistemática e mais difusa pela região metropolitana, com ocorrências em Cariacica (Campo Belo e Vila Isabel) e Vila Velha (São Torquato, Ataíde e Vila Garrido) (ver Figura 1). Segundo as reportagens verificadas e de acordo com o relato de moradores, tratava-se de um quarteto de homens encapuzados e armados que agiam em duas motocicletas, sempre da mesma forma: paravam o ônibus, mandavam os passageiros descerem e ateavam fogo nos ônibus usando galões de gasolina ${ }^{21}$.

No total, oito ônibus foram incendiados na região metropolitana e um último no dia 18, em Aracruz. Como não é plausível supor que grupos de traficantes ou que outros grupos que atuam no mercado de drogas ilícitas fossem os responsáveis por tais atos de vandalismo, tendo em vista que naquele momento de forma alguma

\footnotetext{
20 Entrevista informal, em 13 de setembro de 2017, com um grupo de moradores residentes na Poligonal 1, que reúne as comunidades de São Benedito, Jaburu, Itararé, Floresta, Engenharia, Bonfim, Bairro da Penha e Consolação. Não se mencionam os nomes dos entrevistados em virtude do respeito ao anonimato.

21 Sobre os ataques aos ônibus, podem-se consultar a reportagem de Breno Ribeiro, Homens armados ateiam fogo em ônibus em Vila Velha, publicada em 14 de fevereiro no jornal Folha Vitória (http://m.folhavitoria.com.br); além das duas reportagens assinadas pela redação do jornal $A$ Gazeta, intituladas Grande Vitória tem 7 ônibus atacados desde a paralisação de PMs (publicada no dia 15 de fevereiro ) e Mais um ônibus em chamas é registrado na Grande Vitória (publicada no dia 13 de fevereiro e atualizada no dia 17), ambas disponíveis no site do portal (http://novo.gazetaonline.com.br).
} 
interessava chamar a atenção do Exército ${ }^{22}$, que já patrulhava as ruas desde o dia 6 de fevereiro, embora com contingente limitado não sendo possível identificar os interessados na deflagração dos incêndios, fica a dúvida a respeito dos verdadeiros responsáveis por tais atos, ainda que eles favorecessem na conjuntura daquele momento a desestabilização no espaço urbano.

\section{Figura 1}

Ônibus incendiados na Região Metropolitana da Grande Vitória durante a paralisação da Polícia Militar em fevereiro de 2017

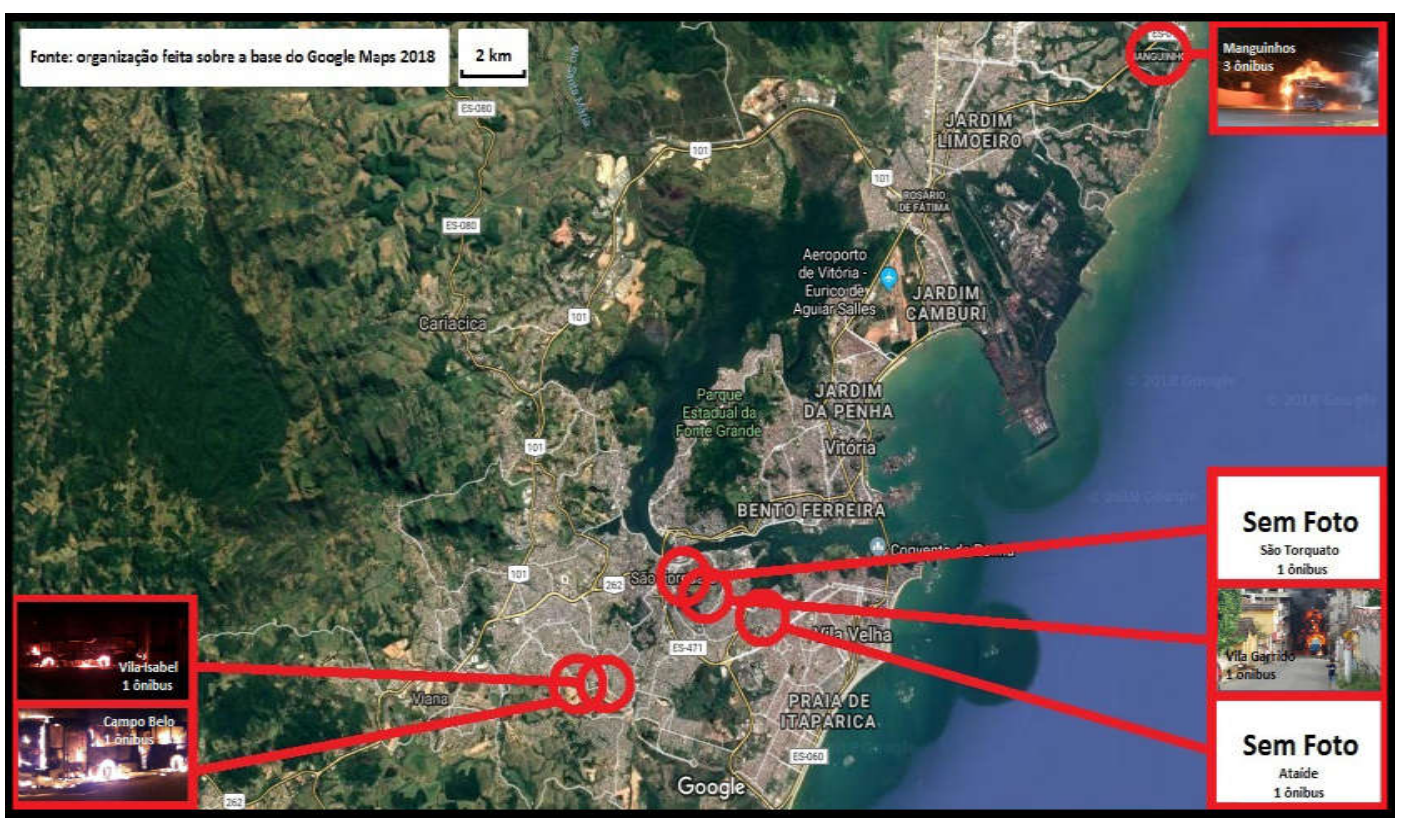

Fonte: Imagem adaptada do Google Maps, 2018.

O retorno do sistema de transporte coletivo à normalidade, embora se desse de forma lenta e com rotas e itinerários alterados, a normalização do transporte público permitia, ainda que parcialmente, a volta dos capixabas a algumas de suas atividades, como ir ao trabalho e dele voltar. Mesmo que não seja possível acusar o movimento grevista de alguma ligação com os incêndios, a normalização da situação, isso é certo, não interessaria ao grupo, que nessa altura, com a presença do Exército não tinha grande margem de manobra e nem mesmo algum trunfo político para pressionar o governo. Todavia, também é certo que o grupo responsável pelos incêndios tinha como objetivo ocupar as manchetes dos jornais e colocar em circulação nas redes sociais, através dos vídeos amadores feitos por espectadores, imagens de ônibus em chamas; vídeos que passaram a circular pela internet, mantendo a sensação de insegurança na população até os últimos dias da paralisação da polícia.

Tudo isso ampliava o sentimento de "caos" e "desordem" urbana, que poderia ser usado - de maneira voluntária ou involuntária - a favor do movimento grevista para pressionar por uma volta rápida dos policiais ao trabalho na condição de

22 Em 6 de fevereiro de 2017, a pedido do governador, foram enviados para o estado 1.200 soldados (das Forças Armadas e da Força Nacional). Esse efetivo foi reforçado posteriormente com mais homens, que permaneceram em ação até o dia 29 de abril, quando a Força Nacional, última tropa a deixar o estado, encerrou suas atividades. Ao todo, mais de 3 mil homens do Exército, da Marinha, da Força Aérea, além da Força Nacional de Segurança estiveram envolvidos na missão capixaba. 
"heróis" que assim procedem para salvar a cidade afundada no "crime", sob os termos de suas respectivas reivindicações. Em efeito, os familiares dos policiais, em seus pronunciamentos na TV e rádio, em mais de uma oportunidade se manifestaram fazendo alusão à figura do "herói" que combate o crime, para conferir legitimidade ao movimento grevista e defendê-lo. Em nenhum momento o movimento foi definido como uma mobilização por direitos trabalhistas, embora, de fato, tratava-se, em sentido imediato, de um movimento de reivindicação por direitos trabalhistas. Daí já se percebe a falta de conscientização de classe, postura apartada da sociedade, e um viés de fundo conservador da mobilização. Ainda sobre a associação da figura do policial a uma ideia de heroísmo, é importante dizer que muitas charges que circularam, em particular no Facebook, conhecidas como memes, faziam alguma comparação com o personagem do Batman e a cidade caótica de Gotham City, com a situação vivida em Vitória. Em uma mensagem lia-se: "Chama o Batman!"

Contudo, como se verificou, não foi isso que ocorreu. Paulo Hartung deixou a cidade se consumir numa incerteza e no medo e numa espécie de violência intestinal por longos dias, enquanto exauriu o movimento grevista por dentro, com todo o tipo de ameaças e persuasão que a máquina pública pode oferecer, usando inclusive a mídia para manobrar a opinião pública contra o movimento grevista, que foi taxativamente, em determinado momento, caracterizado pelo governo, com declarações, nesse sentido, de Paulo Hartung, como irresponsável e inescrupuloso tendo havido certa adesão da opinião pública a esse discurso ${ }^{23}$.

Como resultado, a greve dos policiais, além de ter provocado, voluntária ou involuntariamente, um rastro de saques e mortes, levou a um processo sociopolítico de fragmentação do território da RMGV, com policiamento e patrulhas autônomas que agiam ao seu rigor e critério em determinadas áreas, mas que também se desdobrou em um incipiente processo, embora pontual, de cercamento de área. Foi o que se verificou, por exemplo, na rua Primavera, na região de São Pedro, lugar onde moradores colocaram uma cerca informando que o local estava sendo monitorado 24 horas por câmeras e policiais do bairro (ver Figura 2) ${ }^{24}$.

\section{Figura 2}

Moradores da rua Primavera, uma área onde há predominância de policiais, na Grande São Pedro, colocaram uma cerca informando que o local estava sendo monitorado 24 horas por câmeras e policiais do bairro

\footnotetext{
${ }^{23}$ Paulo Hartung deu uma entrevista sobre a crise da segurança pública no Espírito Santo à repórter Mirian Leitão, no canal de televisão Globo News, no dia 9 de fevereiro de 2017, em que de forma astuta situou o estado do Espírito Santo como refém do movimento grevista, sem em nenhum momento transparecer a responsabilidade do governador pela precarização dos serviços prestados ou a legitimidade do movimento grevista (ao menos no que se refere aos direitos trabalhistas) - essa reportagem encontra-se disponível no site do G1 Globo (http://g1.globo.com/globo), com o seguinte título: Governador do ES, Paulo Hartung, comenta a violência no estado. Antes, no dia 8 , Paulo Hartung já havia dado uma coletiva de imprensa em que tentou manobrar a opinião pública mostrando-se fragilizado e emocionado com a situação do estado. Na ocasião acusou os policiais grevistas de sequestrarem a liberdade dos capixabas, ao afirmar: "É a mesma coisa que sequestrar a liberdade, o direito do cidadão capixaba, e cobrar resgate. Nem por aspecto ético se paga resgate, e nem a lei de responsabilidade fiscal permite isso."

24 Sobre o cercamento realizado por policiais e moradores do referido bairro, pode-se consultar a reportagem População reclama que forças policiais ainda não estão na periferia, do jornal $A$ Gazeta, publicada em 12 de fevereiro de 2017 e disponível no site do jornal (http://novo.gazetaonline.com.br).
} 


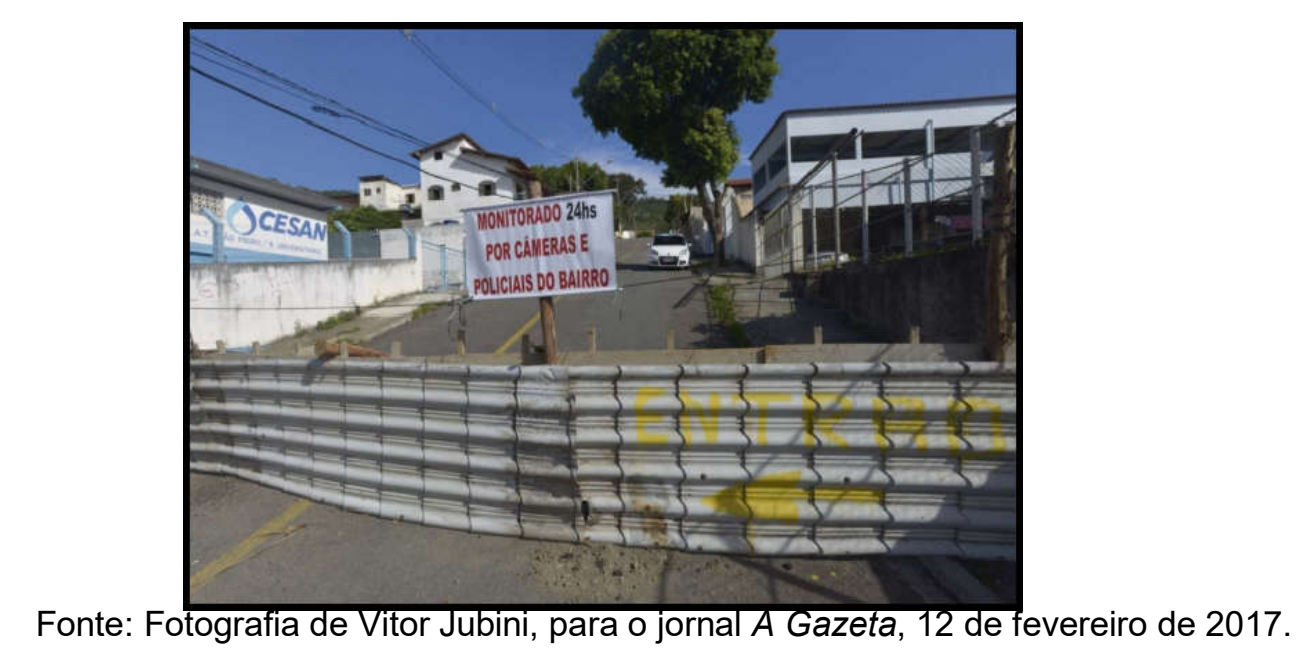

Nos bairros populares, além dos roubos e assaltos, as disputas de territórios por grupos autônomos, pela polícia ou por grupos associados ao comércio ilegal de drogas colaboraram decisivamente para o alto número de homicídios. Foi nos bairros populares que os índices de letalidade durante a greve foram mais altos, caracterizando o que queremos denominar "zonas de morte", onde não havia uma lei vigente, sequer do tráfico, capaz de coibir a violência. Essa conjuntura contribuiu, em alguma medida, para a intensificação da violência, já que, além da violência mais residual, estava em ação uma política interna de disputas territoriais entre grupos armados. Embora nos bairros das classes dominantes de Vitória também tenham ocorrido assaltos e arrombamentos sistemáticos, foi nos bairros populares da região metropolitana que se concentraram os homicídios (ver Figura 3), reiterando-se assim as partilhas já antigas do espaço urbano na região metropolitana entre os mais pobres e os mais ricos (ver a esse respeito ZANOTELLI et al, 2011).

Em alguns bairros populares, sair de casa significava, em tais condições, aventurar-se na mira de homens armados, seja de grupos de extermínio ou traficantes ilegais de drogas, ou, de forma surpreendente, do próprio Exército: qualquer um deles poderia matar (como fizeram) sem dar satisfação de seus atos, agindo sob a batuta dos que definem o estereótipo do jovem pobre e negro residente em bairros populares não apenas como "bandido", mas como um alvo em potencial de uma "guerra" na qual qualquer um poderia ser o "inimigo" 25.

\section{Figura 3}

"Zonas de morte" e áreas de relativa segurança no que se refere à confirmação de homicídios durante a greve da Polícia Militar do Espírito Santo em fevereiro de 2017

\footnotetext{
${ }^{25}$ É importante enfatizar que o discurso de "guerra" ou do "inimigo", juntamente com suas inúmeras metáforas, serve quase sempre aos propósitos da opressão.
} 


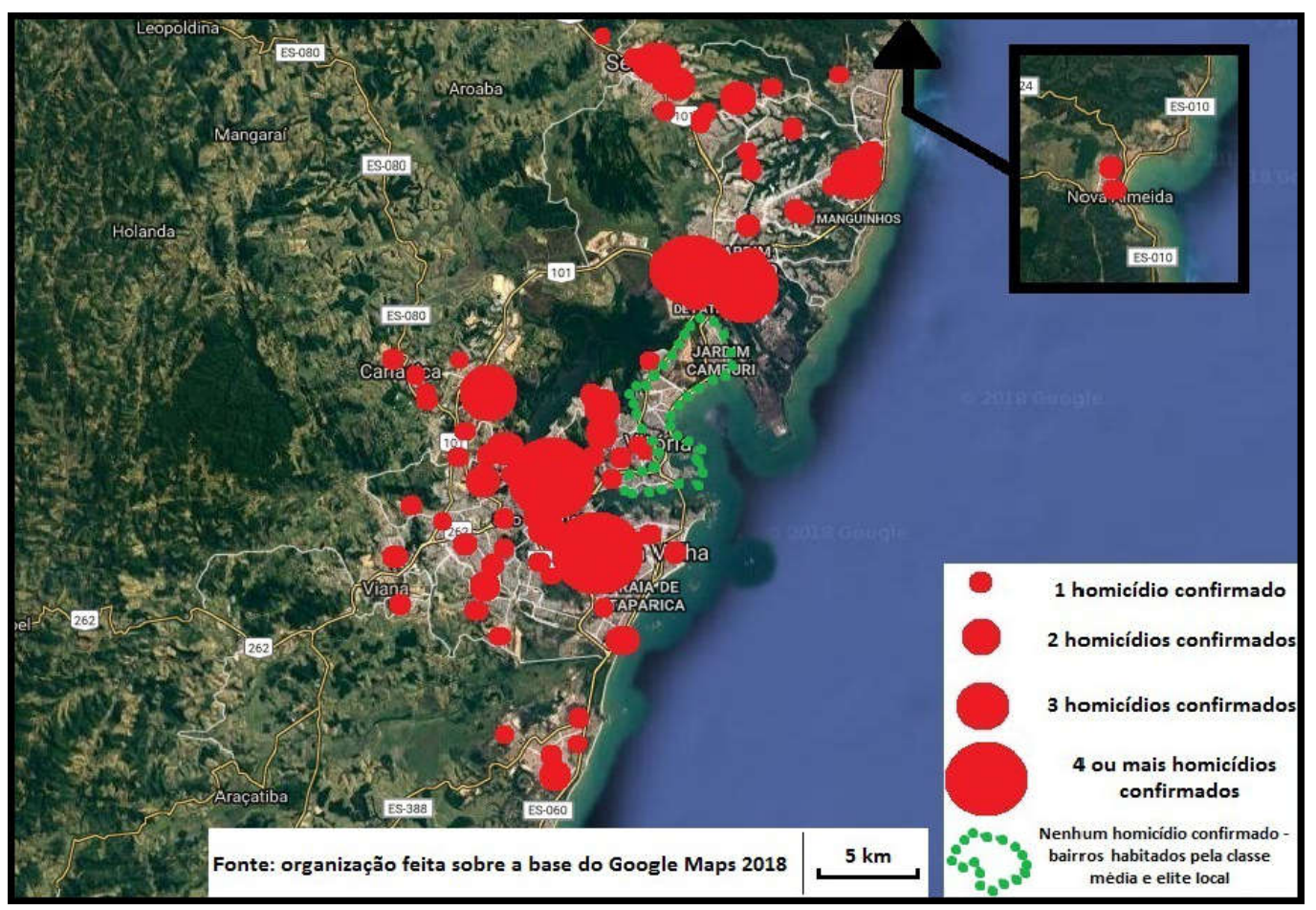

Fonte: DHPP/AOB-ES. Dados da Delegacia de Homicídios e Proteção à Pessoa (DHPP) organizados pela $A O B-E S^{26}$.

\section{O URBICÍDIO DA CIDADE}

A maior parte dos homicídios, como destacado, deu-se em bairros populares onde há concentração das categorias sociais mais pobres. Embora nos bairros de moradia das classes médias e dominantes circular pelas ruas na maioria das vezes não fosse seguro, os crimes nessas áreas quase sempre se restringiram a assaltos, invasões de propriedade, roubos de veículos e arrastões. Como anunciamos o urbicídio assim configurou-se dentro de um contexto social e político confuso, cujos atos deliberadamente visaram atingir as condições de existência na cidade, afetando, sobretudo, os mais pobres que dependem dos equipamentos urbanos públicos.

A violência urbicida, que foi empregada como violência política - com responsabilidade direta do Estado e de seus agentes e dos confrontos suscitados por um darwinismo social -, de fundamento "genocida", de indivíduos pertencentes às classes sociais dominadas, em sua maioria jovens e negros, deu-se, de fato,

${ }^{26}$ Cabe registrar que o Governo do Estado não disponibilizou dados detalhados de homicídios durante a greve da polícia. A análise espacial é gerada pelos dados levantados por grupos independentes e de direitos humanos, auxiliados por advogados, que conseguiram reunir e organizar dados sistematizados, com nomes, local de homicídio, origem das vítimas e natureza da ocorrência, entre outras informações. Embora esses dados estejam incompletos, pudemos espacializar as informações, usando da plataforma do Google Maps, a ocorrência de 124 homicídios por localidade ou bairro (que incluem descoberta de cadáveres, ação policial seguida de morte, latrocínio e demais mortes por armas de fogo) na região de Vitória, Vila Velha, Viana, Cariacica e Serra, durante a greve da Polícia Militar. O resultado é um contraste espacial, no qual bairros populares concentram a maior parte dos homicídios (círculos vermelhos), enquanto nos bairros centrais de Vitória (Praia do Canto, Enseada do Suá, Barro Vermelho, Bento Ferreira, Ilha do Boi, Ilha do Frade, Jardim da Penha, Mata da Praia, Bairro República e Jardim Camburi), onde moram pessoas das classes mais abastadas e que concentram os principais equipamentos administrativos, urbanos e econômicos (circulo verde), não foi registrada ocorrência de homicídios. 
longe das áreas centrais e dos bairros das classes mais abastadas. Entretanto, a inviabilização de uso dos recursos urbanos e a própria negação da cidade, por meio de atos violentos, com o intuito de provocar o medo generalizado, atingiu de forma predominantemente toda a região da capital do estado, afetando, inclusive, os moradores dos bairros de classe média e classe dominante que tiveram que permanecer reclusos em suas residências durante vários dias.

Mas foi nos bairros populares que predominaram os assassinatos, e foi neles, também, que ocorreram de maneira predominante os incêndios de ônibus do transporte público, outra característica urbicida que alvejou a infraestrutura urbana, posta em prática em ações pontuais, mas capazes de criar pânico e fragmentar a cidade. Essas ações se concentraram na segunda fase da greve, quando o Exército já estava operando nas ruas e bairros centrais da região metropolitana. Por conta da violência, falta de segurança e ausência de transporte público, equipamentos e serviços foram suspensos para todos, mas de maneira desigual e com efeitos desiguais, provocando o terror, atingindo majoritariamente os mais pobres e moradores de bairros populares. Filas em frente de supermercados que permaneceriam com portas fechadas foram registradas em vários bairros. O Serviço de Atendimento Móvel de Urgência (SAMU), que atende a população da região metropolitana, também deixou de operar, não atendendo às chamadas nos dias de maior insegurança, afetando principalmente populares que dependem do serviço e que não podiam contar com opção do transporte público para se deslocar até os centros de saúde.

E importante ressaltar que os saques coletivos e quebra-quebras efetivados em vários pontos da região metropolitana são também uma expressão da modalidade de urbicídio de cunho neoliberal às avessas. Foi nesse aspecto que assaltos, roubos e saques sistemáticos, acompanhados de depredação dos estabelecimentos, se deram como reflexo da política de austeridade implantada no Espírito Santo, responsável, ainda, pelo desemprego e pela desigualdade, bem como pela quebra das regras sociais (que se sustentam pela via de um relativo consenso de convivência social ou pelo uso da força "legítima" do Estado), já muito afetadas por uma cultura da propriedade privada, que enaltece a ideia de consumismo e elege o patrimônio com bem supremo. Nesse sentido, ao contrário da situação de lugares como a Bósnia do início dos anos 1990 ou a Síria atualmente, no Espírito Santo não se identificou um embrião urbicida propriamente em virtude de uma guerra convencional, mas de um processo de pilhagem, efetuado não só por oportunistas, mas, também, por pessoas das mais variadas classes sociais, que se supõe sem nenhum vínculo com atividade ilegal, estimuladas por uma profunda crise econômica em âmbito nacional e acentuada no estado desde que Paulo Hartung assumiu o governo ${ }^{27}$.

A violência, em cores e ao vivo, mexeu de alguma forma com o aspecto imaginário do capixaba, já tão alterado, como de qualquer brasileiro, pelo discurso de violência que organiza falas e orienta a violência seletiva contra os mais pobres e negros, apresentados como elementos suspeitos ${ }^{28}$. Nesse sentido, foi impressionante o que ocorreu na tarde do dia 7 de fevereiro, segunda-feira: à

\footnotetext{
27 Inúmeras reportagens e vídeos que circularam pela internet deram destaque aos saques coletivos que ocorreram na RMGV e em outras cidades durante o período da greve. Um vídeo, em particular, chamou a atenção. Nele uma candidata ao posto de vereadora nas eleições de 2016, no município de Cachoeiro de Itapemirim, foi flagrada saindo de uma loja com várias sacolas.

28 Para um debate amplo de como a violência age nesse sentido, ver Caldeira (2000). Para um enfoque regional de como a mídia capixaba age discursivamente banalizando a violência e em alguma medida abrindo espaço para o extermínio seletivo dos sujeitos que viveriam à "margem" da sociedade, ver Zanotelli e Medina (2009).
} 
medida que os veículos e caminhões, posteriormente os tanques do Exército, iam chegando e se adentrando em ruas desertas dos bairros das classes médias e dominantes, as pessoas saíram nas sacadas dos prédios para saudá-los aos gritos, não se sabe ao certo se assim agiam por se considerarem a salvos da barbárie, ou por quererem dizer que estavam ali, também, para assistir ao banho de sangue que continuaria na periferia. Ainda é comum ouvir dos capixabas que durante a greve da polícia "só morreu bandido"; uma evidente reprodução do discurso de extermínio de pobres e negros dos bairros populares.

Dessa forma, nos bairros populares da RMGV, os pobres continuaram vivenciando outro tipo de violência, que vai além da privação do espaço público sentida pelas classes privilegiadas. Muitos habitantes dos bairros populares, trabalhadores que não podem se dar ao luxo de ficar em casa, foram alvejados durante a greve, ou porque foram confundidos com supostos delinquentes, ou porque ficaram no meio do fogo cruzado entre grupos de traficantes, ou porque foram alvo de prováveis grupos de extermínio ${ }^{29}$.

A região metropolitana do estado viveu durante alguns dias uma paralisia de natureza urbicida, se pensarmos que o uso e a apropriação do espaço urbano, a partir das vivências que derivam de suas práticas, foram anulados por atos de violência relacionados com os motivos mais diversos, quando se produziu um clima de insegurança e de medo. A cidade, naqueles dias, como lugar de diferentes interações e lócus da vida urbana, que possibilita a vida no urbano como algo comum, foi sistematicamente atacada por atos de violência política orientados contra a vida e contra o espaço urbano, para negar a cidade, sobretudo aos mais pobres.

Tudo isso se iniciou por indução de uma política de orientação neoliberal que efetuou o desmonte e a precarização dos serviços e equipamentos urbanos, demonstrando que, no que se refere à redução das taxas de homicídios, os números não refletiam, de fato, uma situação duradoura e concreta de aumento da sensação de segurança, que deveria ser seguida pelo aumento do bem-estar da população, algo fora da meta do governo Paulo Hartung. Quando a força que detém o poder "legítimo" de usar a violência, a Polícia Militar, insatisfeita com o governo, saiu de cena, como força legal, todos os atores causadores de instabilidade, que vêm atuando por interesses os mais diversos na região metropolitana e em outros lugares do estado, passaram a se digladiar, agindo, agora, em franca desobediência das leis.

Uma parcela da população parecia estar sedenta de vingança e comemorava execuções sumárias, reagindo a um reflexo simples e sem distância racional em relação aos fatos, obedecendo à emoção cega, que foi e é muito difundida pela mídia. Foram camufladas, dessa forma, as reais motivações sociais e econômicas da desestabilização social: as políticas neoliberais e do Estado mínimo.

Foi essa política de "guerra", voltada, em particular, mas não somente, contra os redutos urbanos dos mais pobres a partir da ideia de negação da cidade, que

\footnotetext{
${ }^{29}$ A presença do Exército nos bairros populares não necessariamente acabou com as mortes, houve casos em que pessoas foram alvejadas por militares, sem que estes apresentassem - mesmo que isso não possa ser visto como algum tipo de justificativa - alguma evidência de que se tratava de alguém cometendo algum tipo de crime, para justificar sua ação. Se nos bairros centrais a presença dos militares foi focada para reestabelecer níveis mínimos de ordem no espaço público, na periferia operou, muitas vezes, por toques de recolher e por condutas enviesadas que ceifaram de forma indiscriminada a vida de algumas pessoas. Matheus Martins Silva, de 17 anos, foi uma das vítimas dos soldados do Exército. Ele saiu da casa de um familiar por achar que a rua estaria segura com a presença do Exército e foi atingido por um tiro de fuzil de um soldado. Matheus em nenhum momento foi acusado de algum ato. Para mais detalhes sobre esse caso e sobre as vítimas da crise da segurança, pode-se consultar a reportagem de Sullivan Silva e Raquel Lopes, Greve da PM: seis meses depois, publicada em 3 de agosto de 2017 e disponível no portal do jornal A Gazeta (http://www.gazetaonline.com.br).
} 
caracterizou o urbicídio durante a greve dos policiais no estado, quando cidadãos ficaram reféns dos diferentes grupos em disputa que agiam na calada da noite, entre o tráfico e as forças militares, sem nenhum tipo de mediação legal reconhecida.

É justamente nessa interface, pautada no artigo, entre militarização e urbicídio, trabalhadas com uma concepção híbrida, como dita antes, e que focaliza, nesse aspecto, a violência política em terreno urbano para reprimir grupos indesejáveis, que a crise econômica e a suposta legitimidade governamental, no caso capixaba, contribui para gerar uma situação de descontrole, que resultou na reativação de perspectivas atávicas na sociedade de opressão.

Este processo foi promovido, de forma simultânea, tanto por grupos armados independentes quanto pelo Estado. No caso do Estado, em particular, ações de seus agentes são ainda mais preocupantes, pois têm oferecido uma orientação com tendência urbicida projetada numa política de segurança pública que atua cada vez mais por vias de exceção na aplicação do monopólio "legítimo" da violência. Mas nos interrogamos: quem detém a legitimidade de indicar o que é legítimo? Não são os cidadãos? Como o Estado se arroga esse direito absoluto, deveria ser algo melhor debatido nas instituições estatais e com a sociedade.

A metaforização do discurso de "caos urbano" - de fim do mundo - no Espírito Santo sem apontar sua operacionalidade e seus responsáveis acabou resultando, voluntária e involuntariamente, durante a greve, em assassinatos indiscriminados, retratados na esfera social como "danos colaterais" e excepcionais, algo sem muita importância, a partir de um pano de fundo racista, capaz de encobrir o assassinato de jovens negros e pobres da periferia e a supressão do espaço comum por atos de violência política orientados contra o espaço urbano e vidas dos moradores de tais bairros, mais do que em qualquer outro lugar. $O$ urbicídio que operou, portanto, no substrato urbano não se pautou na destruição da condição urbana física, como em outros lugares, salvo ataques pontuais ao transporte público e inúmeros saques seguidos de atos de vandalismo, mas causou a paralisação e uma espécie de letargia urbana, através da generalização do medo e anulação da função social da cidade.

\section{CONCLUSÃO}

O urbicídio que se instaurou na RMGV não se deu propriamente em virtude de uma guerra, mas como consequência de uma política neoliberal que amputa os recursos do Estado e diminui os serviços destinados à segurança social e econômica. Tal política, que leva à insegurança urbana, é ativadora e reveladora das contradições fundamentais da sociedade e da paradoxal despolitização dos dominados no tocante às relações sociais e de trabalho.

A greve da Polícia Militar poderia ter servido como forma de mobilização política progressista e questionadora do Estado neoliberal. Mas, como ele se deu num serviço central do Estado que cuida da segurança e como a pecha de "criminosos", atribuída pelo poder estatal aos grevistas, foi aceita como verdadeira por parte de amplos setores da sociedade as reivindicações, de maneira voluntária e involuntária, por parte dos policiais, originários, diga-se de passagem, na sua imensa maioria, das classes populares, desencadeou processos ambíguos. Estes, instrumentalizados, resultaram numa cidade sob "sequestro" por vários dias desnudando, assim, as contradições sociais não resolvidas e os contraditórios processos de dominação que politizam no sentido de revelar uma sociedade que age 
por grupos e corporações, ao invés de se pensar em relações de classes sociais. $O$ "Outro" foi considerado previamente culpado, e nele foram projetadas todas as insatisfações, transformado em bode expiatório para ser lançado no real do deserto da cidade, onde tudo pode acontecer, sobretudo durante os eventos, chegando-se ao irreparável, à morte dos cidadãos de "segunda classe" e, em última instância à "morte da cidade": morte e vida das cidades, dialética política urbana, dessa vez, não somente pela intervenção nos aspectos urbanos, mas por um "fechamento social" por meio do qual instaurou-se um urbicídio ${ }^{30}$.

Encobre-se, assim, e se reforça o individualismo e o cada um por si, justificando o darwinismo social do início do liberalismo econômico, que é ressuscitado na contemporaneidade na guerra de todos contra todos, na invocação do indivíduo "neoliberal", do puro interesse, da mera troca, reduzindo a imagem dos homens em sociedade à luta pelos seus interesses, dando-se uma opção entre uma jaula de aço e uma prisão urbana para os considerados "marginais": um estado social de insegurança, sem saída aparente.

Ora, a sociedade é diversa, complexa, os espaços de criação coletiva são concretos e as relações sociais não se restringem ao Estado, mas uma gestão catastrófica dos governos no leme do Estado levou a uma desestabilização social e urbana que deixará por muito tempo suas marcas, apesar do "esquecimento" coletivo, que enterrou no fundo de seu inconsciente o trauma urbano relatado. Demonstrou-se no artigo que os efeitos do neoliberalismo são deletérios para a vida em comum e para o urbano e que a barbárie do urbicídio nos espreita logo ali na esquina.

\section{REFERÊNCIAS}

Aliados de Bolsonaro teriam impulsionado o motim de PMs no Espírito Santo. Folha Vitória. Vitória, Brasil, 25 de fev. 2017. Disponível em: <http://m.folhavitoria.com.br>. Acesso em: 20 de fev. 2018.

BOURGUIGNON, Natalia. Greve da PM: advogada diz que adolescentes foram vítimas de extermínio. A Gazeta. Vitória, Brasil, 03 de ago. 2017. Disponível em: <http://novo.gazetaonline.com.br>. Acesso em: 20 de fev. 2018.

CABALLERO, Miguel. Vitória tem noite de 'cidade fantasma' e amanhece sem ônibus. O Globo. Rio de Janeiro, Brasil, 07 de fev. 2017. Disponível em: <http://oglobo.globo.com/brasil>. Acesso em: 20 de fev. 2018.

CALDEIRA, Teresa P. do Rio. Cidade de muros: crime, segregação e cidadania em São Paulo. São Paulo: ed. 34, Edusp, 2000.

\footnotetext{
30 A perspectiva e lente de análise assumida por nós é a do urbicídio, concebido como política de violência urbana de natureza destrutiva em que sua motriz, isto é, sua modalidade de negação da cidade, se dá por meio da violência direta ou indiretamente vinculada ao aspecto militar e que age sobre o substrato urbano. No caso capixaba esse fenômeno se desenvolveu sobre um forte alicerce de uma política econômica de cunho neoliberal marcada pelo desmonte do Estado, que induziu a um quadro de violência (em que grupos diferentes agiam armados) no substrato social da cidade, conforme seus interesses. Embora o enfoque do urbicídio esboce esse ponto de vista, é pertinente dizer que sua concepção dialoga com a ideia de "fobópole" de Souza (2008), segundo o qual o medo se propaga na cidade, ou de "ecologia urbana do medo" de Davis (2001), segundo o qual se fabrica um desastre, como aconteceu no Espírito Santo.
} 
COUTINHO, Danieleh. Sindipol: em 2017 o Espírito Santo registrou 222 mortes a mais do que no ano anterior. ES Hoje. Vitória, Brasil, 2 de jan. 2018. Disponível em: <http://eshoje.com.br>. Acesso em: 20 de fev. 2018.

COWARD, Martin. Urbicide in Bosnia. In: GRAHAM, Stephen (Org.). Cities, war and terrorism: towards an urban geopolitics. Oxford: Blackwell Publishing Ldt., 2004, p. 154-171.

Urbicide: the politics of urban destruction. Nova York: Routledge, 2009.

DAVIS, Mike. Ecologia do medo. Rio de Janeiro: Record, 2001.

Do céu ao inferno. Século diário. Vitória, Brasil, 08 de fev. 2017. Disponível em: <http://seculodiario.com.br>. Acesso em: 20 de fev. 2018.

DARDOT, Pierre; LAVAL, Christian. Comum: ensaio sobre a revolução no século XXI. São Paulo: Boitempo, 2017.

FANON, Francis. Peau noire, masques blancs. Paris: Le Seuil, col. Points, 2001 (1952).

FERNANDES, Vilmara. Greve da PM: 10 militares sentam no banco dos réus. A Gazeta. Vitória, Brasil, 16 de mai. 2017. Disponível em: <https://www.gazetaonline.com.br/>. Acesso em: 20 de mai. 2018.

FREGONESE, Sara. The urbicide of Beirute? Geopolitics and the built environment in the Lebanese civil war (1975-1976). Political Geography, v. 28, p. 309-318, 2009.

GRAHAM, Stephen . Constructing urbicide by bulldozer in the occupied territories. In: (Org.). Cities, war and terrorism: towards an urban geopolitics. Oxford:

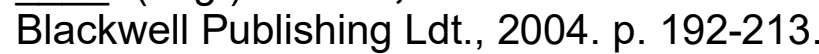

Cities under siege: the new militar urbanism. Londres: Verso, 2011.

Grande Vitória tem 7 ônibus atacados desde a paralisação de PMs. A Gazeta. Vitória, 14 de fev. 2017. Disponível em: <http://novo.gazetaonline.com.br>. Acesso em: 20 de fev. 2018.

HARTUNG, Paulo. Governador do ES, Paulo Hartung, comenta a violência no estado. G1 Globo. Rio de Janeiro, Brasil, 09 de fev. 2017. Disponível em: <http://g1.globo.com/globo>. Acesso em: 20 de fev. 2018. Entrevista concedida a Mirian Leitão para o Globo News.

HARTUNG, Paulo. Hartung sobre a anistia a PMs: "Decisão política grave e irresponsável". A Gazeta. Vitória, 16 de jan. 2019. Disponível em: <http://www.gazetaonline.com.br>. Acesso em: 16 de jan. 2019. 
HOFFMANN, Tyago. O desmonte do Espírito Santo. O Globo. Rio de Janeiro, Brasil, 23 de fev. 2017. Disponível em: <http://www.//oglobo.globo.com>. Acesso em: 20 de fev. 2018.

Mais um ônibus em chamas é registrado na Grande Vitória. A Gazeta. Vitória, Brasil, 13 de fev. 2017. Disponível em: <http://novo.gazetaonline.com.br)>. Acesso em: 20 de fev. 2018.

MACHADO, Viviane. Crise da segurança faz 1 ano e onda de homicídios volta a crescer no ES. G1 Globo. Rio de Janeiro, Brasil, 5 de fev. 2018. Disponível em: <https://g1.globo.com/>. Acesso em: 20 de fev. 2018.

Mortes durante greve da PM ainda continuam sem esclarecimento. Folha Vitória. Vitória, Brasil, 01 de fev. 2018. Disponível em: <https://novo.folhavitoria.com.br>. Acesso em: 20 de fev. 2018.

Nassif: trava-se no ES a primeira grande batalha de desmonte do Estado brasileiro. Brasil 247. São Paulo, Brasil, 13 de fev. 2017. Disponível em: <http://www.brasil247.com>. Acesso em: 20 de fev. 2018.

NASSIF, Luis. Xadrez de Paulo Hartung, fiscalista que a Globo inventou, por Luis Nassif. Jornal GGN. Brasil, 23 de nov. 2017. Disponível em: <https://jornalggn.com.br>. Acesso em: 20 de fev. 2018.

O que de fato reivindicam os policiais militares do Espírito Santo? A Gazeta. Vitória, Brasil, 09 de fev. 2017. Disponível em: <https://www.gazetaonline.com.br>. Acesso em: 20 de fev. 2018.

População reclama que forças policiais ainda não estão na periferia. A Gazeta. Vitória, Brasil, 12 de fev. 2017. Disponível em: <http://novo.gazetaonline.com.br>. Acesso em: 20 de fev. 2018.

RIBEIRO, Breno. Homens armados ateiam fogo em ônibus em Vila Velha. Folha Vitória. Vitória, Brasil, 14 de fev. 2017. Disponível em: <http://m.folhavitoria.com.br>. Acesso em: 20 de fev. 2018.

SHARP, Deen. Urbicide and the arrangement of violence in Syria. In: SHARP, Deen; PANETTA, Claire (Orgs.). Beyond the square: urbanism and the Arab Uprisings. New York: Urban Research, 2016, p. 118-140.

SHAW, Martin. New wars of the city: relationship of "urbicide" and "genocide". In: GRAHAM, Stephen (Org.). Cities, war and terrorism: towards an urban geopolitics. Oxford: Blackwell Publishing Ldt., 2004, p. 141-153.

SILVA, Sullivan; LOPES, Raquel. Greve da PM: seis meses depois. A Gazeta. Vitória, Brasil, 03 de ago. 2017. Disponível em: <http://www.gazetaonline.com.br>. Acesso em: 20 de fev. 2018.

SOUZA, Marcelo Lopes de. Fobópole: o medo generalizado e a militarização da questão urbana. Rio de Janeiro: Bertrand Brasil, 2008. 
VERLI, Caíque. Deputados Estaduais aprovam a anistia a PMs grevistas. A Gazeta. Vitória, Brasil, 16 de jan. 2019. Disponível em: <http://www.gazetaonline.com.br>. Acesso em: 16 de jan. 2019.

VOGAS, Vitor. Governo investiga possível atuação de grupos de extermínio. A Gazeta. Vitória, Brasil, 11 de fev. 2017. Disponível em: <http://novo.gazetaonline.com.br>. Acesso em: 20 de fev. 2018.

Problemas no Paraíso. A Gazeta. Vitória, Brasil, 11 de fev. 2017. Disponível em: <http://novo.gazetaonline.com.br>. Acesso em: 20 de fev. 2018.

ZANOTELLI, Cláudio et al.. Atlas da criminalidade no Espírito Santo. São Paulo: Annablume, Fundação de Amparo à Pesquisa do Espírito Santo - FAPES, 2011.

ZANOTELLI, Cláudio; MEDINA, Jorge. Conselho Nacional de Segurança Pública do Ministério da Justiça. Análise dos discursos sobre a criminalidade a delinquência na mídia capixaba e seus efeitos sobre a política de segurança e a percepção de (in)segurança. Brasília, Brasil, 2009. 